\title{
How Multinational' Social Performance Influences Performance of Subsidiary in China: The Role of Distance
}

\author{
Peng Zou ${ }^{1}$, Feng Zhang ${ }^{1} \&$ Jun Ye ${ }^{1}$ \\ ${ }^{1}$ School of Management, Harbin Institute of Technology, Harbin, China \\ Correspondence: Peng Zou, 13 Fayuan Str. School of Management, Harbin Institute of Technology, Harbin \\ 150001, China. E-mail: zoupeng@ @it.edu.cn
}

Received: March 14, 2015

Accepted: June 8, 2015

Online Published: July 25, 2015

doi:10.5539/ibr.v8n8p1

URL: http://dx.doi.org/10.5539/ibr.v8n8p1

\begin{abstract}
This paper addresses how corporate social responsibility of multinationals in China influences their Chinese subsidiaries' performance. Using panel data regression, (1) we investigate the effects of corporate social moderating effects of institutional and geographic distances between their home countries and China. Our findings show, first, that subsidiaries' corporate social performance is associated positively with their profit in China. Second, we find that the greater the cultural, economic, and geographic distances between the home country and China, the less likely it is that a subsidiary will benefit from corporate social responsibility. We enrich the theoretical understanding of the institutional conditions under which corporate social responsibility leads to specific outcomes by adding new institutional elements - the differences of culture and the economies between multinationals' host and home countries. Our findings suggest that although corporate social responsibility is still new to China, being socially responsibility provides financial benefits to multinationals. Their global and local corporate social responsibility strategies have to adjust based on local cultures and economic levels, especially with respect to fundamental beliefs about spirituality and values. The paper fulfilled the research gap between multinationals' social practices and their performance in host countries at the subsidiary level by providing empirical evidence concerning the responses to corporate social responsibility initiatives in emerging markets and clarifying the conditions under which foreign affiliates' corporate social responsibility engagement in the host country can gain better returns in local markets.
\end{abstract}

Keywords: corporate social responsibility, multinational, financial performance, cultural differences, economic differences, geographic distance

\section{Introduction}

Corporate social responsibility (CSR) research has focused on developed countries traditionally. With an increasing footprint by multinationals in emerging markets (Aulakh \& Kotabe, 2008) like Brazil, Russia, India and China, multinationals have begun emphasizing CSR in their business strategies in emerging markets. They have become more sensitive and responsive to the problems and needs of the local business environments and now take the CSR efforts in these countries in which they operate. This compliance-oriented motivation is foundational to multinationals' CSR (Bartlett, Ghoshal, \& Beamish, 2007). Moreover, CSR activities such as labor practices, local community donation and pollution prevention also serve as maintaining legitimacy and coping mechanisms for the liability of foreignness (LOF) plaguing foreign affiliates and hindering their survivability in host countries (Campbell, Eden, \& Miller, 2012). The two factors may motivate multinationals to increase their awareness of CSR and improve related practices of their affiliates through self-regulation (Christmann \& Taylor, 2001; Meyer, 2004). But the question is, concerning multinationals as profit-seeking organizations, whether their CSR engagement is desirable and deserves acceptance and support among local stakeholders and whether multinationals' performance can benefit from engaging CSR in host country (Dowell, Hart, \& Yeung, 2000).

Although some literature has linked CSR with stakeholders' respond (e. g. Berens, Van Riel, \& Van Bruggen, 2005; Luo \& Bhattacharya, 2006) and financial performance (Margolis \& Walsh, 2003; Orlitzky et al., 2003; Klassen \& McLaughlin, 1996; Cohen, Fenn, \& Naimon, 1995; Nehrt, 1996; Hart \& Ahuja, 1996) most empirical work has been restricted to multinationals in developed markets. Little empirical research on this issue has been conducted in emerging markets (Dowell, Hart, \& Yeung, 2000; Wang \& Qian, 2011). To our knowledge, little 
direct evidence is about effects of multinationals' CSR in host countries on their subsidiaries' performance.

Previous international business researches have studied the impact of multinationals' business strategies on their subsidiary performance (e.g., Birkinshaw \& Morrison, 1995; Jarillo \& Martinez, 1990; Lin \& Hsieh, 2009; Taggart, 1998; Tian \& Slocum, 2014). However, research is lacking on clarifying the nature of the link between social practices and subsidiary performance (Muller, 2006). Multinationals face potential divergences from local operational practices of the home country in the host country (Tian \& Slocum, 2014). Cultural distance has been cited as an explanation for a wide range of multinational strategies and organizational characteristics (e.g. Barkema, Bell, \& Pennings, 1996; Grosse \& Trevino, 1996; Roth \& O’Donnell, 1996; Gomez-Mejia \& Palich, 1997; Morosini, Shane, \& Singh, 1998). The distance between home and host countries (e.g., institutional or geographic distance) has been identified as a cause of increased LOF because it generates greater unfamiliarity and discriminatory vulnerabilities for foreign firms in host countries (Eden \& Miller, 2004). Thus, the distance between multinationals' home and host countries may influence the CSR effect on their performance.

How firms' CSR is relevant to their performance depends on how stakeholders reactions to its CSR (Sen \& Bhattacharya, 2001). Although studies on stakeholder reactions to CSR are advanced for developed market environments (e.g. Berens, Van Riel, \& Van Bruggen, 2005; Torelli, Monga, \& Kaikati, 2012; Sen \& Bhattacharya, 2001), such evidence is still scarce for emerging markets (Wang \& Qian, 2011). We derived the evidence in the context of a transition economy - China. A transition economy provides a useful sociopolitical context in which to extend the divergences caused by distance in a profound and fine-grained manner. The characteristics of emerging markets such as China present certain challenges to firms engaging in CSR. It becomes crucial to understand (1) if multinationals' CSR practices in host countries influence their subsidiaries' performance in China, and (2) how distances between multinationals' home and host countries moderate the relationships between their CSR activities and subsidiaries' performance in China.

To answer these questions, we drew upon international business, CSR, and distance literature to develop a framework for explaining the role that CSR plays on subsidiaries' performance. First, we investigated whether multinationals' CSR in host countries resulted in significant gains on subsidiaries' performance in China, the central issue to managers when devoting resources to CSR efforts. We investigate whether subsidiaries' profit was affected by their CSR initiatives, according to scores based on their CSR contributions valued by Fortune Magazine from 2010 to 2012. Second, we examined whether such influences of CSR differ for firms according to distances between home and host countries. Specifically, we examined the moderate effect of distance between home and host countries.

The remainder of this article is organized as follows. In the following section, we provide the theory and develop our hypotheses concerning the impact of multinationals' CSP on market performance in China. Then, we describe the data and estimation method used in this study, and we present the empirical findings. Finally, we conclude with a summary, a discussion of managerial implications, and suggestions for further research.

\section{Theory and Hypothesis Development}

\subsection{The Research Context}

The unique China's country-specific factors and institutional environments let us observe large variations in some of the specific factors potentially relevant to the relationship between multinational corporate philanthropy and performance. It is a challenge for multinational in China to engage in CSR as McWilliams and Siegel's definition in 2001 in a transient economy in which there are neither strong nor well-enforced state regulations nor private independent organizations that closely monitor the behavior of multinationals. Along with the ever-increasing CSR spending in developed countries, there has also seen a growing concern of CSR in China. The social and environmental issues that have arisen with the rapid economic growth of China, such as product safety, income inequality, pollution, create an urgent need for firms and policy makers to consider the social and environmental influences when making their decisions. However, the characteristics of China's markets present some particular challenges to firms doing CSR. For example, compared to the developed countries where CSR has been a well-adopted concept, it is relatively new to stakeholders in China and thus it is unknown to marketers whether stakeholders (i.e., consumers and investors) respond to the CSR initiatives. There are also differences between western business ethics and the traditional Chinese culture about social values rooted in Confucianism. Furthermore, it can be difficult to motivate companies to consider the environmental and social consequences of their operations in China, as most of which still struggle for survival and economic growth. The inadequate governance and guidance in China make it unclear to firms on what and how to conduct CSR. 


\subsection{Multinationals' CSP and Their Performance in China}

While scholars have offered various definitions of CSR (McWilliams, Siegel, \& Wright, 2006; Rodriguez, Siegel, Hillman, \& Eden, 2006), perhaps the most appropriate for our study is the definition by McWilliams and Siegel (2001): "actions that appear to further some social good, beyond the interests of the firm and that which is required by law" (p. 117) because large western multinationals were perceived as primarily proving elusive of local governments due to their economic power and ability to shift resources and production across borders (Christmann, 2004). And there is neither strong nor well-enforced state regulations in China and Multinationals mainly rely on self-regulation (Christmann \& Taylor, 2001; Meyer, 2004). The two characteristics of research context satisfy the definition "beyond that mandated by government". Multinationals' CSR activities in host countries include programs or initiatives that benefit the stakeholders of the host countries in which their subsidiaries operate (Lam, 2009).

In China, there are both the challenges for doing CSR and the increasing needs of CSR, there might be two possible market responses to multinationals' CSP. On the one hand, CSR is new for consumers in China; as a result, related actions may not affect consumers' purchasing decisions or lead to increased sales. Although multinationals can fulfill their social responsibility in host countries with such actions as product-responsive efforts to improve product quality and environmental-responsive investments for a cleaner environment, few local Chinese consumers consider environmental and safety issues seriously in their buying decisions (Lam, 2009). Moreover, the income of majority consumers are still quite low (Tian \& Slocum, 2014). For example, China's PCDI in 2010 was equivalent to US $\$ 4,000$, yet the PCDI in the United States was $\$ 35,000$ for the same year. Furthermore, Japan's PCDI in 2010 was equivalent to US\$26,000. Based on limited income, Chinese consumers may make purchasing decisions solely on cost effectiveness (i.e., price), rather than on the long-term social benefits for emerging markets (Sheth, 2011; Torelli, Monga, \& Kaikati 2012; Yin \& Zhang, 2012). As a result, CSR activities may not increase consumer's purchase.

On the other hand, because the economic and social environments differ for emerging markets and mature economies, multinationals' CSP may enhance performance significantly. First, while CSR is a new concept for consumers in emerging markets, it may be attractive to them as a response to a serious product-harm crisis. Product-harm crises have not only caused loss of life, but have impacted consumers' confidence severely in matters regarding product safety. For example, a product-harm crisis initiated by contaminated "Sanlu" infant milk powder and the resulting infant deaths, hospitalization of more than 1,000 babies, and harm to more than 100,000 other babies as of December 2008 has had a prolonged impact on consumers' confidence in China's domestic dairy industry. In the wake of this event, $30 \%$ of the public demonstrated more trust in multinationals, saying that they will try their best to purchase from multinationals even pay much higher prices (Iposos, 2009).

Furthermore, firms with good working environments and comprehensive health care programs engender loyalty from employees, thereby fostering improved production efficiency and enhanced creativity. Additionally, modeling good citizenship helps firms win support from the government and local community (Mishra \& Suar, 2010; Waddock \& Graves, 1997; Vidaver-Cohen \& Altma, 2000), which could further enhance their operational efficiency. The ultimate desired outcome is improved market performance.

Finally, a respectable performance of CSR engagement as business practice and targeted at philanthropic interaction with the community (Homburg, Stierl, \& Bornemann, 2013) can increase local industrial customers' and suppliers' expected sustainability of a multinational with good CSP rating and thus generates orders and sufficient supplies. Specifically, CSR can operate as a signal in emerging markets that an organization is managed skillfully. According to the Alexander and Buchholz (1982), strong CSP levels are indicators of superior management skills and slack resources. Such firms balance their interactions with key groups of stakeholders and sustain good relationships with them. These positive relationships have the potential to resolve issues related to LOF by valuing local employees as well as outside subsidiaries (consumers and communities). Since host country stakeholders often lack information about a foreign affiliate in an emerging market, they rely on certain signals to infer firms' abilities when making purchases or supply selections.

Given the rising concerns about environmental and social issues in emerging markets and the efforts by multinationals to overcome LOF, we have hypothesized that a multinational's respectable CSP is associated positively with its subsidiaries' market performance:

H1: A multinational's CSR is associated positively with the performance of its subsidiaries.

\subsection{Moderating Effect of Distance}

The distance between home and host countries, in particular the institutional and geographic distance, has been 
predicted to increase liability of foreignness by generating higher unfamiliarity and discriminatory hazards for foreign firms in host countries (Eden \& Miller, 2004). We argue that culture distance, economic distance and geographic distance have combined effect on the relationship between a multinational's CSR and the market performance of subsidiaries.

\subsubsection{Cultural Distance}

Cultural distance reflects differences in national cultures between the home country of the multinational and its countries of operation. The topic is of broad interest in international business research (Ricks, Toyne, \& Martinez, 1990). Culture, in general, is the homogeneity of characteristics that separates one human group from another. It provides a society's characteristic profile with respect to norms, values, and institutions, thus affording an understanding of how societies manage exchanges (Hofstede, 1980, 1984; Trompenaars \& Hampden-Turner, 1998). At the national level, culture is an aggregate of individual values. The concept of culture at the national level captures the typical individual priorities within a society, which "reflect the central thrust of their shared enculturation" (Schwartz, 1999).

When examining the role of cultural distance, most studies theorize that as the cultural differences between a multinational's home country and host market increase, the underlying ability of the multinational to operate effectively in the host market decreases (Gomez-Mejia \& Palich, 1997; Hennart \& Larimo, 1998). Generally, increased operational difficulties resulting from cultural distance are derived from a lack of understanding of the norms, values, and institutions that afford social exchanges across markets. Cultural distance may lead to greater complexity and uncertainty for host country stakeholders as they respond to a multinational's CSR choices.

First, there may be divergence between multinational's CSR guidance and Chinese stakeholder's acceptance. For example, many multinationals expend considerable effort toward reducing pollution emissions and supporting the green supply chain in China, but some of these organizations have been criticized by the Chinese public and media for not donating more from their sizeable profits earned after the Sichuan earthquake in 2008 (Iposos, 2009). The divergence of perceptions regarding appropriate CSR activities between multinationals and the Chinese people may result from differences between western business ethics and the traditional Chinese view about social values. Port and Kramer (2006) best described the CSR principle followed by most multinationals from west countries: "Each company must select issues that intersect with its particular business. The essential test that should guide CSR is not whether a cause is worthy but whether it presents an opportunity to create shared value - a meaningful benefit for society that is also valuable to the business."

However, Chinese traditional culture rooted in Confucianism holds that "anyone rich or success people should benefit others." The majority of Chinese people value morality or "righteousness" higher than "benefit" (Wang, Rouna, \& Rojewski, 2005). Therefore, individuals businesses are obligated to help vulnerable groups, whether or not this devotion will incur benefits (Buttery \& Leung, 1998). With this divergent view, Chinese stakeholders do not perceive multinationals' CSR as altruistic benevolence they have desired, thus they may not reward multinationals' CSR engagement.

Second, there may be divergence of the targeted stakeholders' priority of CSR between western tenet and Chinese normal. Stakeholder theory proposes the distinction between primary and secondary stakeholders (Freeman, 1984). Primary stakeholders (e. g. customers, employees and investors) are those who engage in market exchange with the firm and considered most critical because the treatment of them has the most influence on firm performance (Maignan, Ferrell, \& Ferrell 2005; Berman et al., 1999). In contrast, secondary stakeholders (e. g. the community and nonprofit institutions) (Lankoski, 2009) are those who influence or affect, or are influenced or affected by, the corporation, but are not engaged in transactions with the corporation (Clarkson, 1995). Realistically, multinationals will not disregard shareholders' wealth by investing in social affairs of local community that offer no return on investment. As example of treatment difference between primary and secondary stakeholders, Airbus Industrie firstly expressed sympathy for its customers and employees in China instead of victims after the Sichuan earthquake in 2008 (http://finance.sina.com.cn/200805/001746372.shtml).

However, Chinese social normal would not agree the distinction held by stakeholder theory. Traditionally, the Chinese are deeply influenced by the Buddhist, Daoist and Confucian philosophies. Buddhists believe that compassion is a principal virtue in life. People should be and benevolent. Similarly, Daoism emphasizes that a person should be aware of the needs of others without discrimination in treating people (Wang \& Qian, 2011). Although the rapid development of the Chinese economy has resulted in positive changes in the public's perceptions of the wealthy, Chinese people are still deeply influenced by traditional values (Leung, 2008). Under the morality standard, any corporations should try best to indiscriminatingly help all people who are suffering from disaster no matter they are engaged in transactions with the corporation. An investigation executed by Ipsos 
showed that only 34\% Chinese public agreed that multinationals set a good example for Chinese enterprises in CSR regarding selection criterion and process for targeted stakeholders although they positively evaluated multinationals' philanthropy in China (Ipsos, 2011). When multinationals engage CSR in China, their discriminatory treatment of stakeholders may make Chinese public uncomfortable. Thus they may not reward multinationals' CSR engagement.

Consequently, stakeholders' attitudes may weaken the positive effects of multinationals' CSR on marketing effectiveness and efficiency. Thus, we expect a decreasing positive effect of multinationals' CSR on performance as cultural differences increase. Therefore:

H2: Cultural distance weakens the positive effect of a multinational's CSR on the market performance of subsidiaries.

\subsubsection{Economic Distance}

Economic distance is exhibited in differences in consumer wealth/income between countries, along with differences in costs and quality of production (Ghemawat, 2001). If the economic distance between the home and host countries is small, the countries should be similar in terms of their income and wealth profiles; thus, they should be more alike in consumer tastes, according to the country similarity theory in international economics (Linder, 1961). Economic similarity is reflected in commonalities of consumers' attitudes and lifestyles (Hewitt, Roth, \& Roth, 2003). One might expect, therefore, that countries with similar income/wealth levels would exhibit similar levels of social norms and regulations. It would follow logically that their firms would engage in comparable levels of CSR, suggesting that the smaller the economic distance, the more likely it is for the foreign affiliate to adapt to the interests of stakeholders in the host country.

Moreover, there is paradox for multinationals if the economic distance between the home and host countries is great. If the host country is poorer than the home country and if a multinational adopts the same CSR practice for host and home countries, such as labor rates or welfare, it gives up the comparative advantage regarding labor cost in host countries, and departures from the original goal of pursuing profit by operating globally (Christmann, 2004). On the other hand, if a multinational adopts different levels of CSR for host and home countries, maintaining low local labor rates, the global NGO and media may accuse the company of discriminatory treatment of employees. Given the rapidly growing number of Internet users, such criticism could create an Internet buzz and destroy corporate reputations and brand images of the multinational. Therefore, as economic distance increases, we expect that it will become more difficult for the multinational to satisfy stakeholders in the host country through CSR activities that leverage market performance. Thus:

H3: Economic distance weakens the positive effect of a multinational's CSR on subsidiaries' market performance.

\subsubsection{Geographic Distance}

We argue that geographic distance which reflects physical remoteness has an important impact on the effects of a multinational's CSR in a host country. Some multinationals having subsidiaries in China also produce in other countries such as their own home country. Klein and Dawar (2004) have emphasized that CSR has a halo effect on customer judgments. Chinese consumers may associate the CSP of multinationals in China with that of multinationals in other countries. On one hand, some CSR activities are concerned with air, water and soil pollution. Greater geographic distance from China leads to less possibility that the pollution transfer to and harm environment in China through natural circulation. We may expect Chinese consumers to be more sensitive to the pollution of their own environment than distant places. On the other hand, social psychology theory suggests that empathy - the feeling resulting from an individual imagining himself or herself in another person's position (that is, imagining interpersonal distance to be zero) - increases the perception of attachment and the likelihood of an empathetic response (Ray, 1998). Some CSR activities concern workers (working conditions, salary, security, etc.) and we may expect Chinese consumers to be particularly sensitive to the working conditions of their fellow citizens because of empathy - general speaking, fellow citizen's interpersonal distance is less than foreigners. Greater geographic distance is expected to lead to less empathy of Chinese stakeholders to other citizenship workers who work in distant places. Thus, local stakeholders will be less likely sensitive to CSR practices of multinational in distant home countries. Therefore:

H4: Geographic distance weakens the positive effect of a multinational's CSR on subsidiaries' market performance. 


\section{Method}

\subsection{Data}

We empirically examined the impact of multinationals' CSR in host countries on their subsidiaries' financial performance by referring to multinationals listed in "Fortune China CSR Ranking 2011-2013" (Fortune, 2011, 2012, 2013). Prior research has used similar CSR rankings according to the Fortune 500, which highlights the United States' most admired corporations (McGuire, Sundgren, \& Schneeweis, 1988; Luo \& Bhattacharya, 2006). The Fortune China CSR Ranking, introduced in 2011, aims to raise awareness of CSR, highlight relevant practices, and instigate meaningful conversations between companies and stakeholders. The populations of ranked multinational companies were derived from the Fortune Global 500 2010-2012 lists and screened to include companies with significant revenues in mainland China (based on data from China's Ministry of Commerce).

Data on the multinational were obtained from Fortune Global 500 2010-2012 lists (Fortune, 2010, 2011, 2012). Data for subsidiaries in China were obtained from China's Ministry of Commerce Census, which was published midway through the period studied. The data for rivals and local markets in China were obtained from Fortune China 500 2010-2012 lists (Fortune, 2010, 2011, 2012) and China National Bureau of Statistics. Some observations were excluded because of missing data. Our final sample included a panel of 175 foreign affiliates from 20 home countries including the United States, Canada, Japan, Korea, Hong Kong, Singapore, Germany, France, England, the Netherlands, Finland, and Australia.

\subsection{Measures}

\subsubsection{Dependent Variable}

Subsidiary's Performance (SP). As Tian and Slocum (2014) used profit as a metric measure for subsidiary's performance, we used the logarithm of total profit to construct the dependent variable. .

\subsubsection{Independent Variables}

CSP. The CSP scores for multinationals were obtained from Fortune China CSR Ranking 2011-2013. The rankings were created to record local CSR agendas. Initially, a selection of the world's leading CSR ratings, reporting standards (e.g., ISO26000), and prominent environmental and social standards were studied, from which key criteria were identified. Then, additional tailored interviews with experts were conducted to understand China's current situation. The critical CSR issues were identified, and performance indicators were extracted and rearranged to form a ranking framework. The framework was structured around industry-recognized parameters of three domains: 1) Environment: environmental management, pollution prevention, resource use, climate change, and biodiversity; 2) Society: labor practices, customers, community, supply chain, and human rights; 3 ) Governance: board structure and diversity, fair marketplace practices, CSR management, and CSR communication. The ranking team and other experts scored performance indicators of each sample multinational according to their CSR records in China, which were derived from annual financial, and CSR reports, other formal documents published by firms and their official websites.

\subsubsection{Moderate Variables}

We computed cultural distance using the Kogut and Singh (1988) formula, which is based on Hofstede's four original culture dimensions: individualism-collectivism, masculinity-femininity, uncertainty avoidance, and power distance. The cultural distance between a focal firm's home country $c$ and China is indicated by:

$$
\sum_{d=1}^{4}\left(I_{d o}-I_{d c}\right)^{2} / 4 V_{d}
$$

where $I_{d o}$ is the value of the Hofstede index for cultural dimension d of country o, c indicates China, and $V_{d}$ represents the inter-country variance of the Hofstede index along dimension d. While the Kogut and Singh index has been criticized as problematic (Håkanson \& Ambos, 2010; Tung \& Verbeke, 2010), it remains the most widely used index for cultural distance.

Geographic distance was calculated by the average "city-to-city" great circle distance (Bouquet \& Birkinshaw, 2008), which encompasses thousands of miles between the capital cities of a focal firm's home country and host country.

We measured economic distance as the absolute value of the difference in real gross domestic product per capita between the focal firm's home country and the host country in a given year. Then, we transformed this variable using the following formula: 


$$
-\log \left(1+\left|G D P_{p c} C N-G D P_{p c} h o\right|\right)
$$

Where "CN" represents China and "ho" is the focal foreign affiliate's home country in year $t$ (Campbell, Eden, $\&$ Miller, 2012).

\subsubsection{Control Variables}

We acknowledged that firm performance may be influenced by many factors, including economic level of development, stage of development of the firm in a particular country, various differences by product lines, and different strategies (Tian \& Slocum, 2014). According to our purpose, we focus on subsidiary's market environment and its legitimacy among stakeholders.

Market experience was measured as the natural logarithm of the difference between the subsidiary's date of establishment in China and the year for which performance was measured (Miller \& Eden, 2006). Suchman (1995) and Hillman and Wan (2005) argue that a firm's credibility and legitimacy among stakeholders depend partly on the length of time the firm has been active in the respective country. In particular, increasing familiarity over time may allow the firm to manage its relationships with the various stakeholders more effectively (Hillman $\&$ Wan, 2005).

We also controlled for the characteristics of the local market. Local density has been shown to affect firm performance (Miller \& Eden, 2006); it has been included to control for the munificence of the local environment. We measured local density as the natural logarithm of the number of firms in a particular sector in a year. Table 1 lists the variables.

Subsidiary size, measured as a natural logarithm of asset size, is included as a control since larger foreign affiliates have more resources (Barney, 1991) and potentially greater ability to devote to market.

\section{Results}

Tables 1 and 2 present summaries of variable illustrations and statistics.

Table 1. Illustration of variables

\begin{tabular}{ll}
\hline Variable & Measure \\
\hline Subsidiary performance $(S P)$ & logarithm of total profit \\
CSR performance $(C S P)$ & Score of Fortune China CSR Ranking \\
Cultural distance $(C D)$ & $\sum_{d=1}^{4}\left(I_{d o}-I_{d c}\right)^{2} / 4 V_{d}$ \\
Geographic distance $(G D)$ & $\begin{array}{l}\text { Natural logarithm for thousands of miles between the capital cities of the } \\
\text { focal firm's home country and the host country. }\end{array}$ \\
Economic distance $(E D)$ & -log $(1+\mid \mathrm{GDPpc}$ CN - GDPpc hol \\
Subsidiary size $(S S)$ & Natural logarithm of asset size \\
Market experience $(M E)$ & Natural logarithm of the difference between the subsidiary's date of \\
Local density $(L D)$ & establishment in China and the year for which performance was measured. \\
\hline
\end{tabular}

Table 2. Summary of variables statistics

\begin{tabular}{llllll}
\hline Variables & Mean & SD & Variables & Mean & SD \\
\hline SP & 1.503 & 0.992 & LD & 21.481 & 0.995 \\
CSP & 10.922 & 4.121 & CD & 2.7 & 1.2 \\
SS & 8.985 & 1.909 & GD & 6.9 & 4.1 \\
ME & 0.386 & 0.142 & ED & 9.3 & 3.2 \\
\hline
\end{tabular}

We ran multicollinearity diagnostics using a linear regression model because, as Menard (2001) notes, the 
functional form of the model is irrelevant for diagnosing collinearity. All individual variable VIF values were below 2, indicating that multicollinearity did not affect our results. Due to the panel structure of our data, we used the Hausman test to choose either a fixed-effects or a random-effects model. The test rejected the null hypothesis, indicating that the fixed-effects estimator was consistent. Therefore, we used panel regression with fixed-effects modeling. We entered only single interaction of CSR and distance into the regression model each time because of the highly linear relationship among the interactions:

$$
S P_{i t}=\alpha+\beta_{1} C S P_{i t}+\beta_{2} S_{i z} e_{i t}+\beta_{3} M E_{i t}+\beta 4 L D i t+\beta_{5} \text { Distance }+\beta_{6} C S P_{i t} \times \text { Distance }+\xi_{i t}
$$

Table 3 presents the findings from panel regression models and results in terms of regression coefficients. Model 1, Model 3, and Model 5 include only independent and control variables. CSR performance, subsidiary size, and market experience positively impact MP. Local density negatively impacts market performance. The results of models 1-6 all show the significant and positive impact of CSR performance on market performance (at $\alpha=$ 0.01 ), which provides support for $\mathrm{H} 1$.

The results for Model 2 (Table 3) show that the coefficient for the interaction of CSR and cultural distance is negative and statistically significant $(\mathrm{p}<0.05)$, which provides support for $\mathrm{H} 2$. The results for Model 4 show that the coefficient for the interaction of CSR and economic distance is negative and statistically significant ( $<$ 0.05), which provides support for H3. The results for Model 6 show that the coefficient for the interaction of CSR and geographic distance is negative and statistically significant $(\mathrm{p}<0.05)$, which provides support for H4.

Table 3. Results of panel regression models

\begin{tabular}{|c|c|c|c|c|c|c|c|}
\hline & Model 1 & Model 2 & Model 3 & Model 4 & Model 5 & Model 6 & Model 7 \\
\hline Constant & $2.851 * *$ & 2.414 & $2.535^{*}$ & 2.530 & $2.660 *$ & $2.570 * *$ & $2.713^{* *}$ \\
\hline SS & $1.032 * * *$ & $0.925^{* * * *}$ & $0.882^{* * *} *$ & $0.948 * * *$ & $0.893 * * *$ & $0.905^{* * *}$ & $0.885^{* * *}$ \\
\hline ME & $0.406^{* * *}$ & $0.284^{* *}$ & $0.284^{* *}$ & $0.303^{* *}$ & $0.300^{* *}$ & $0.200^{* *}$ & $0.209 * *$ \\
\hline LD & $-0.124 * *$ & -0.119 & -0.123 & $-0.119^{*}$ & $-0.126^{*}$ & $-0.118^{*}$ & $-0.126^{*}$ \\
\hline CSP & & $0.131^{* *}$ & $0.141^{* *}$ & $0.131 * *$ & $0.133^{* *}$ & $0.101 * *$ & $0100 * *$ \\
\hline $\mathrm{CD}$ & & -0.027 & -0.024 & & & & \\
\hline $\mathrm{CSP} \times \mathrm{CD}$ & & & $-0.070 * *$ & & & & \\
\hline $\mathrm{ED}$ & & & & -0.009 & -0.007 & & \\
\hline $\mathrm{CSP} \times \mathrm{ED}$ & & & & & $-0.074 * *$ & & \\
\hline GD & & & & & & -0.038 & -0.032 \\
\hline $\mathrm{CSP} \times \mathrm{GD}$ & & & & & & & $-0.045^{* *}$ \\
\hline $\mathrm{F}$ & $57.206^{* * *}$ & $59.086 * * *$ & $53.392 * * *$ & $60.000 * * *$ & $54.284 * * *$ & $52.482 * * *$ & $66.975 * * *$ \\
\hline Within R2 & 0.542 & 0.563 & 0.570 & 0.556 & 0.563 & 0.567 & 0.572 \\
\hline
\end{tabular}

Note. Dependent variable: $\mathrm{SP}, \mathrm{N}=175 * \mathrm{p}<0.1 ; * * \mathrm{p}<0.05 ; * * * \mathrm{p}<0.01$.

\section{Discussion and Conclusion}

In light of the value added in exploring multinationals social strategies across diverse contexts, we choose the CSR practices of multinationals in China as our empirical context. China, as the biggest emerging country in the world with vastly different social, cultural and political structures from the West, provides a good sample for broadening multinationals CSR knowledge (Gao, 2009). This study conceptualizes and empirically examines a framework concerning 1) the influence of multinationals' CSR in emerging markets on their performance in local markets and 2) differential impacts of multinationals based on distance differences between home and host countries.

\subsection{Research Contributions}

First, this study contributes to the international business literature by providing empirical evidence concerning market responses to CSR initiatives in China. Even though China is still in the early stage of CSR strategizing, which is a challenge for foreign subsidiaries in China to take socially responsible actions, this study reveals that multinationals engaging in CSR activities can gain performance. Although prior studies have concerned the link 
between multinationals' social practices and performance (Dowell, Hart, \& Yeung, 2000), we are the first to show this link at the subsidiary level. This finding suggests to multinationals that CSR is not only an efficient coping mechanism for overcoming LOF but also an alternative marketing tool. To business scholars, this finding underscores the importance of integrating CSR into their core business management for brand-building in emerging markets because engaging in CSR is not just a responsibility that firms have to fulfill in the social domain; it is also an effective strategy for creating awareness and generating values in emerging markets.

Second, we concluded that the greater the distance between the home countries of foreign affiliates and China, the less likely benefits from CSR efforts on performance. The finding contributes to the CSR literatures focusing on the institutional level. The relationship between CSR and outcomes varies primarily due to institutional effects (Agnis \& Glavas, 2012). We enrich understanding of institutional conditions under which CSR leads to specific outcomes by adding new institutional elements (the differences of culture, economy between multinationals' host and home countries). These can allow managers to determine how they position their globally and locally CSR strategy according to enhance market success.

Finally, this study also contributes to distance literature by clarifying the moderating effect under which foreign affiliates' CSR engagement in the host country can obtain better returns in local markets. (Campbell, Eden, \& Miller, 2012) found that distance affects the MNC's willingness and ability to engage in CSR abroad. We advance the stream of research on multinationals' CSR and distance by revealing the moderating effect of distance on the relationship between multinationals' CSR and market performance. We have shown that geographic and institutional distances make stakeholders less likely to respond positively to foreign affiliates' CSR performance because increased distances create the tendency for multinationals to lack adequate understanding regarding norms, values, and institutions of China in which subsidiaries are located. The results of our study shed light on the effects of distance on CSR performance by foreign affiliates.

\subsection{Managerial Implications}

Our study can also provide enlightenment regarding management practices in China. First, we found that this market responds positively to a multinational's CSR, thus implying that CSR is not simply a strategy that builds credibility and legitimacy among stakeholders but also a strategy that creates brand imaging for consumers, leading to improved performance in China. To multinationals operating in China, our findings suggest that CSR as a non-business endeavor can enhance subsidiaries' performance. This is also an encouraging finding for multinationals, suggesting that although China is in the early stage of developing CSR, doing CSR plays an important role in building a competitive edge. Further, it provides financial benefits to them.

Second, our findings also provide some guidance for multinationals regarding effective CSR actions. Specifically, our findings imply that while engaging in CSR is valuable, not all firms benefit equally. Our results indicate that the geographic and institutional distances between host and home countries of multinationals weaken the positive effect of CSR on subsidiaries' market performance. Thus, distance remains an obstacle for multinationals that anticipate gaining in local markets with CSR investments in host countries. A possible solution for overcoming obstacles created by distance may be "Think global, Act local", first suggested by Honda Motors (Quelch \& Hoff, 1986): CSR strategies of multinationals have to extend or adjust mix based on local cultures and economic level, especially with respect to fundamental beliefs about spirituality and values.

\subsection{Future Research}

Our study has several limitations. As the first step toward examining the financial performance of social responsibility investment in emerging markets, this study focuses on a rapidly growing and emerging market - China. To generalize our findings, future works are necessary for examining other emerging markets such as Brazil, India, South Africa, etc. Furthermore, this study only uses data covering three years. Future research to study the long-term impact (i.e., consecutive years) of a multinational's CSR on product-market performance would be valuable. Furthermore, future research could focus on different ways of measuring CSR performance and market performance of a multinational's subsidiaries or methods for controlling more variables such as investment in branding or publicity, the number of countries multinationals is operating in, decentralization of CSR decision.

\section{Acknowledgments}

This research was partially funded by a research grant from National Science Foundation of China under project No. 71272174 and Science Foundation of Heilongjiang Province under project No. G201304.

\section{References}

Aguinis, H., \& Glavas, A. (2012). What we know and don't know about corporate social responsibility: A 
review and research agenda. Journal of Management, 38(4), 932-968. http://dx.doi.org/1177/0149206311436079

Alexander, G., \& Buchholz, R. (1982). Corporate social responsibility and stock market performance. Academy of Management Journal, (21), 479-486. http://dx.doi.org/10.2307/255728

Aulakh, P. S., \& Kotabe, M. (2008). Institutional changes and organizational transformation in developing economies. Journal of International Management, $209-216$. http://dx.doi.org/10.1016/j.intrnan.2008.04.001

Barkema, H. G., Bell, J. H. J., \& Pennings, J. M. (1996). Foreign entry, cultural barriers, and learning. Strategic Management Journal, $151-166$. http://dx.doi.org/10.1002/(SICI)1097-0266(199602)17:2<151::AID-SMJ799>3.0.CO;2-Z

Barney, J. (1991). Firm resources and sustained competitive advantage. Journal of Management, 17(1), 99-120. http://dx.doi.org/10.1177/014920639101700108

Bartlett, C. A., Ghoshal, S., \& Beamish, P. W. (2007). Transnational management: Text, cases, and readings in cross-border management (5th ed.). New York, NY: McGraw-Hill. http://dx.doi.org/10.1108/pr.2001.30.1.119.1

Berens, G., Van Riel, C., \& Van Bruggen, G. (2005). Corporate associations and consumer product responses: The moderating role of corporate brand dominance. Journal of Marketing, 69(July), 35-48. http://dx.doi.org/10.1509/jmkg.69.3.35.66357

Berman, S. L., Andrew, C. W., Suresh, K., \& Jones, T. M. (1999). Does stakeholder orientation matter? The relationship between stakeholder management models and firm financial performance. Academy of Management Journal, 42(5), 488-506. http://dx.doi.org/10.2307/256972

Birkinshaw, J. M., \& Morrison, A. J. (1995). Configurations of strategy and structure in subsidiaries of multinational corporations. Journal of International Business $\quad$ Studies, $26(4), \quad 729-754$. http://dx.doi.org/10.1057/palgrave.jibs.8490818

Bouquet, C., \& Birkinshaw, J. (2008). Weight versus voice: How foreign subsidiaries gain attention from corporate headquarters. Academy of Management Journal, 51(3), 577-601. http://dx.doi.org/10.5465/AMJ.2008.32626039

Buttery, E. A., \& Leung, T. K. P. (1998). The difference between Chinese and Western negotiations. European Journal of Marketing, 32(3-4), 374-389. http://dx.doi.org/10.1108/03090569810204652

Campbell, T. J., Eden, L., \& Miller, S. R. (2012). Multinationals and corporate social responsibility in host countries: Does distance matter? Journal of International Business Studies, 43, 84-106. http://dx.doi.org/10.1057/jibs.2011.45

Christmann, P. (2004). Multinational companies and the natural environment: Determinants of global environmental policy standardization. Academy of Management Journal, (47), 747-760. http://dx.doi.org/10.2307/20159616

Christmann, P., \& Taylor, G. (2001). Globalization and the environment: Determinants of firm self-regulation in China. Journal of International Business Studies, 32(3), 439-458. http://dx.doi.org/10.2139/ssrn.277452

Clarkson, M. E. (1995). A stakeholder framework for analyzing and evaluating corporate social performance. Academy of Management Review, 20(1), 92-117. http://dx.doi.org/10.5465/AMR.1995.9503271994

Cohen, M., Fenn, S., \& Naimon, J. (1996). Environmental and financial performance. Washington, D. C.: IRRC.

Dowell, G. W. S., Hart, S. L., \& Yeung, B. (2000). Do corporate global environmental standards create or destroy market value? Management Science, 1059-1074. http://dx.doi.org/10.1287/mnsc.46.8.1059.12030

Eden, L., \& Miller, S. R. (2004). Distance matters: Liability of foreignness, institutional distance and ownership strategy. In M. Hitt, \& J. Cheng (Eds.), Advances in international management (Vol. 16, pp. 187-221.) Amsterdam, Netherlands: Elsevier. http://dx.doi.org/10.1108/S1571-5027(2013)0000026023

Fisman, R., Heal, G., \& Nair, V. B. (2008). A model of corporate philanthropy. Working paper, Columbia University and University of Pennsylvania. http://dx.doi.org/10.1007/s10551-008-9982-y

$\begin{array}{lllllll}\text { Fortune. } & \text { (2011). } & \text { Retrieved } & \text { on } & \text { July } & 7, & 2013\end{array}$ http://www.fortunechina.com/rankings/c/2011-03/15/content_51895.htm

Fortune. (n. d.). Retrieved on July 1, 2013 from http://www.fortunechina.com/fortune500/node_4302.htm 
Fortune. (n. d.). Retrieved on June 7, 2013 from http://money.cnn.com/magazines/fortune/global500/

Freeman, R. E. (1984). Strategic management: A stakeholder approach. Pitman, Boston, MA.

Gao, Y. (2009). Corporate social performance in China: Evidence from large companies. Journal of Business Ethics, 89(1), 23-35. http://dx.doi.org/10.1007/s10551-008-9982-y

Ghemawat, P. (2001). Distance still matters: The hard reality of global expansion. Harvard Business Review, 79(8), 137-147. http://dx.doi.org/10.1225/8533

Gomez-Mejia, L. R., \& Palich, L. E. (1997). Cultural diversity and the performance of multinational firms. Journal of International Business Studies, 28, 309-335. http://dx.doi.org/10.1057/palgrave.jibs.8490103

Grosse, R., \& Trevino, L. J. (1996). Foreign direct investment in the United States: An analysis by country of $\begin{array}{lllll}\text { origin. Journal of International Business } & \text { Studies, }\end{array}$ http://dx.doi.org/10.1057/palgrave.jibs.8490129

Håkanson, L., \& Ambos, B. (2010). The antecedents of psychic distance. Journal of International Management, 16(3), 195-210. http://dx.doi.org/10.1016/j.intman.2010.06.001

Hart, S. A., \& Ahuja, G. (1996). Does it pay to be green? An empirical examination of the relationship between emission reduction and firm performance. Business Strategy and the Environment, 5, 30-37. http://dx.doi.org/10.1002/(SICI)1099-0836(199603)5:1<30::AID-BSE38>3.0.CO;2-Q

Hennart, J. F., \& Larimo, J. (1998). The impact of culture on the strategy of multinational enterprises: Does national origin affect ownership decisions? Journal of International Business Studies, 29, 515-538. http://dx.doi.org/10.1057/palgrave.jibs.8490005

Hewitt, K., Roth, M. S., \& Roth, K. (2003). Conditions influencing headquarters and foreign subsidiary roles in marketing activities and their effects on performance. Journal of International Business Studies, 34(6), 567-585. http://dx.doi.org/10.1057/palgrave.jibs.8400054

Hillman, A., \& Wan, W. P. (2005). The determinants of MNE subsidiaries' political strategies: Evidence of institutional duality. Journal of International Business Studies, 36, 322-340. http://dx.doi.org/10.1057/palgrave.jibs.8400137

Hofstede, G. (1980). Culture's consequences. Beverly Hills, CA: Sage.

Hofstede, G. H. (1984). Cultural dimensions in management and planning. Asia Pacific Journal of Management, l(2), 81-99. http://dx.doi.org/10.1007/BF01733682

Homburg, C., Stierl, M., \& Bornemann, T. (2013). Corporate social responsibility in business-to-business markets: How organizational customers account for supplier corporate social responsibility engagement. Journal of Marketing, 77(6), 54-72. http://dx.doi.org/10.1509/jm.12.0089

Ipsos. (n. d.). Retrieved from http://www.ipsos.com.cn/sites/default/files/EN\%20200901_1.pdf

Ipsos. (n. d.). Whitepaper multinationals through the eyes Chinese people. Retrieved on January 7, 2014 from http://www.ipsos.de/assets/files/presse/2010/publikationen/Ipsos.pdf

Jarillo, J. C., \& Martinez, J. I. (1990). Different roles for subsidiaries: The case of multinational corporations in Spain. Strategic Management Journal, 11(7), 501-512. http://dx.doi.org/10.1002/smj.4250110702

Klassen, R., \& Mclaughlin, C. (1996). The impact of environmental management on firm performance. Management Science, 42, 1199-1214. http://dx.doi.org/10.1287/mnsc.42.8.1199

Klein, J., \& Dawar, N. (2004). Corporate social responsibility and consumers' attributions and brand evaluations in a product-harm crisis. International Journal of Research in Marketing, 21, 203-217. http://dx.doi.org/10.1016/j.ijresmar.2003.12.003

Kogut, B., \& Singh, H. (1988). The effect of national culture on the choice of entry mode. Journal of International Business Studies, 19(3), 411-432. http://dx.doi.org/10.1057/palgrave.jibs.8490394

Lam, M. L. (2009). Beyond credibility of doing business in China: Strategies for improving corporate citizenship of foreign multinational enterprises in China. Journal of Business Ethics, 87(Supplement 1), 137-146. http://dx.doi.org/10.1007/s10551-008-9803-3

Lankoski, L. (2009). Differential economic impact of corporate responsibility issues. Business and Society, 48(2), 206-224. http://dx.doi.org/10.1177/0007650307306635

Leung, K. (2008). Chinese culture, modernization, and international business. International Business Review, 17, 
184-187. http://dx.doi.org/10.1016/j.ibusrev.2008.02.009

Lin, S. L., \& Hsieh, A. T. (2009). International strategy implementation: Roles of subsidiaries, operational capabilities, and procedural justice. Journal of Business Research, 11, 11-21. http://dx.doi.org/10.1016/j.jbusres.2008.11.008

Linder, S. B. (1961). An essay on trade and transformation. Almqvist \& Wicksell, Stockholm.

Luo, X., \& Bhattacharya, C. B. (2006). Corporate social responsibility, customer satisfaction, and market value. Journal of Marketing, 70(October), 1-18. http://dx.doi.org/10.1509/jmkg.70.4.1

Maignan, I., Ferrell, O. C., \& Ferrell, L. (2005). A stakeholder model for implementing social responsibility in $\begin{array}{lllll}\text { marketing. } \quad \text { European Journal of } & \text { Marketing, }\end{array}$ http://dx.doi.org/10.1108/03090560510610662

Margolis, J. D., \& Walsh, J. P. (2003). Misery loves companies: Rethinking social initiatives by business. Administrative Science Quarterly, 48(2), 268-305. http://dx.doi.org/10.2307/3556659

McGuire, J., Sundgren, A., \& Schneeweis, T. (1988). Corporate social responsibility and firm financial performance. Academy of Management Journal, 31(4), 854-872. http://dx.doi.org/10.2307/256342

McKinsey. (2012). Meet the 2020 Chinese consumer. Retrieved from http://china.mckinseyquarterly.com/Strategy/Strategic_Thinking/Meet_the_2020_Chinese_Consumer_2939 2012-3-24

McWilliams, A., \& Siegel, D. (2001). Corporate social responsibility: A theory of the firm perspective. Academy of Management Review, 26(1), 117-127. http://dx.doi.org10.5465/AMR.2001.4011987

McWilliams, A., Siegel, D., \& Wright, P. (2006). Corporate social responsibility: Strategic implications. Journal of Management Studies, 43(1), 1-18. http://dx.doi.org/10.1111/j.1467-6486.2006.00580.x

Menard, S. (2001). Applied logistic regression analysis (2nd ed.). Thousand Oaks, CA: Sage.

Meyer, K. E. (2004). Perspectives on multinational enterprises in emerging economics. Journal of International Business Studies, 35(4), 259-290. http://dx.doi.org/10.1057/palgrave.jibs.8400084

Miller, S. R., \& Eden, L. (2006). Local density and foreign subsidiary performance. Academy of Management Journal, 49(2), 341-355. http://dx.doi.org/10.5465/AMJ.2006.20786081

Mishra, S., \& Suar, D. (2010). Does corporate social responsibility influence firm performance of Indian companies? Journal of Business Ethics, 95(4), 571-601. http://dx.doi.org/10.1007/s10551-010-0441-1

Morosini, P., Shane, S., \& Singh, H. (1998). National cultural distance and cross-border acquisition performance. Journal of International Business Studies, 29, 137-158. http://dx.doi.org/10.1057/palgrave.jibs.8490029

Muller, A. (2006). Global versus local CSR strategies. European Management Journal, 24(2-3), 189-198. http://dx.doi.org/10.1016/j.emj.2006.03.008

Nehrt, C. (1996). Timing and intensity effects of environmental investments. Strategic Management Journal, 17, 535-547. http://dx.doi.org/10.1002/(SICI)1097-0266(199607)17:7<535::AID-SMJ825>3.3.CO;2-0

Orlitzky, M., Schmidt, F. L., \& Rynes, S. L. (2003). Corporate social and financial performance: A meta-analysis. Organization Studies, 24(3), 403-441. http://dx.doi.org/10.1177/0170840603024003910

Porter, E. M., \& Kramer, M. R. (2006). Strategy and society: The link between competitive advantage and

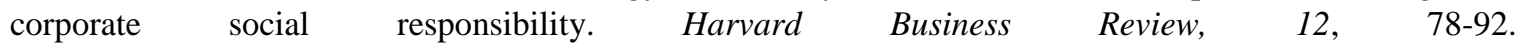
http://dx.doi.org/10.1108/sd.2007.05623ead.006

Quelch, J. A., \& Hoff, E. J. (1986). Customizing global marketing. Harvard Business Review, 64, 59-68.

Ray, L. (1998). Why we give: Testing economic and social psychological accounts of altruism. Polity, 30(3), 383-415. http://dx.doi.org/10.2307/3235207

Ricks, D., Toyne, B., \& Martinez, Z. (1990). Recent developments in international management research. Journal of Management, 16, 219-253. http://dx.doi.org/10.1177/014920639001600202

Rodriguez, P., Siegel, D., Hillman, A., \& Eden, L. (2006). Three lenses on the multinational enterprise: Politics, corruption, and corporate social responsibility. Journal of International Business Studies, 37(6), 733-746. http://dx.doi.org/10.1057/palgrave.jibs.8400229

Roth, K., \& O’Donnell, S. (1996). Foreign subsidiary compensation strategy: An agency theory perspective. Academy of Management Journal, 39, 678-703. http://dx.doi.org/10.2307/256659 
Schwartz, S. H. (1999). A theory of cultural values and some implications for work. Applied Psychology: An International Review, 48(1), 23-47. http://dx.doi.org/10.1111/j.1464-0597.1999.tb00047.x

Sen, S., \& Bhattacharya, C. B. (2001). Does doing good always lead to doing better? Consumer reactions to corporate social responsibility. Journal of Marketing Research, 38(May), 225-244. http://dx.doi.org/10.1509/jmkr.38.2.225.18838

Servaes, H., \& Tamayo, A. (2013). The impact of corporate social responsibility on firm value: The role of customer awareness. Management Science, 59(5), 1045-1061. http://dx.doi.org/10.1287/mnsc.1120.1630

Sheth, J. N. (2011). Impact of emerging markets on marketing: Rethinking existing perspectives and practices. Journal of Marketing, 75(July), 166-182. http://dx.doi.org/10.1509/jmkg.75.4.166

Suchman, M. C. (1995). Managing legitimacy: Strategic and institutional approaches. Academy of Management Review, (20), 571-610. http://dx.doi.org/10.5465/AMR.1995.9508080331

Taggart, J. H. (1998). Strategy shifts in MNC subsidiaries. Strategic Management Journal, 19(7), 663-681. http://dx.doi.org/10.1002/(SICI) 1097

Tian X., \& Slocum, W. J. (2014). What determines MNC subsidiary performance? Evidence from China. Journal of World Business, 49(3), 421-430. http://dx.doi.org/10.1057/jibs.2012.32

Torelli, C. J., Alokparna, B. M., \& Andrew, M. K. (2012). Doing poorly by doing good: Corporate social responsibility and brand concepts. Journal of Consumer Research, 38(5), 948-963. http://dx.doi.org/10.1086/660851

Trompenaars, F., \& Hampden-Turner, C. (1998). Riding the waves of culture (2nd ed.). New York, NY: McGraw-Hill.

Tung, R. L., \& Verbeke, A. (2010). Beyond Hofstede and GLOBE: Improving the quality of cross-cultural research. Journal of International Business Studies, 41(8), 1259-1274. http://dx.doi.org/10.1086/660851

Vidaver-Cohen, D., \& Altma, B. W. (2000). Corporate citizenship in the new millennium: Foundation for an architecture of excellence. Business and Society Review, 105(1), 145-168. http://dx.doi.org/10.1111/0045-3609.00069

Waddock, S. A., \& Graves, S. B. (1997). The corporate social performance-financial performance link. Strategic Management Journal, 18(4), 303-319. http://dx.doi.org/10.1002/(SICI)1097-

Wang, H., \& Qian C. (2011). Corporate philanthropy and corporate financial performance: The roles of stakeholder response and political access. Academy of Management Journal, 54(6), 1159-1181. http://dx.doi.org/10.5465/amj.2009.0548

Wang, J., Wang, G. G., Rouna, W. E. A., \& Rojewski, J. W. (2005). Confucian values and the implications for international HRD. Human Resource Development International, 8(3), 311-326. http://dx.doi.org/10.1080/13678860500143285

Yin, J., \& Zhang, Y. (2012). Institutional dynamics and corporate social responsibility (CSR) in an emerging country context: Evidence from China. Journal of Business Ethics, 111(2), 301-316. http://dx.doi.org/10.1007/s10551-012-1243-4

\section{Copyrights}

Copyright for this article is retained by the author(s), with first publication rights granted to the journal.

This is an open-access article distributed under the terms and conditions of the Creative Commons Attribution license (http://creativecommons.org/licenses/by/3.0/). 